\title{
Language Learning while Negotiating Race and Ethnicity Abroad
}

\section{Tracy Quan}

University of Delaware

\begin{abstract}
:
Despite institutional and national focus on the importance of study abroad (SA) in U.S. higher education, the number of students of color abroad is still disproportionately low (Institute of International Education, 2017). Moreover, there is limited literature examining how race and ethnicity shapes experiences abroad, despite SA research highlighting how identity negotiation influences language learning in the SA context (Kinginger, 2013). This study presents the cases of two U.S. students - an Iranian-American and an African- and Mexican-American - studying in Spain. Through journals, interviews, surveys, and the Versant for Spanish oral test, this study illustrates how these participants rejected negative racial and ethnic positionings by withdrawing from host country nationals and eventually re-evaluating experiences to align with their desired identities. Both learners improved their Versant post-SA but their linguistic confidence in their Spanish language capabilities did not increase. The study concludes with implications for creating more inclusive and supportive SA programs.
\end{abstract}

Study abroad has been heavily emphasized across higher education institutions, as evidenced by the Institute of International Education's (IIE) initiative, Generation Study Abroad, which aims to double the number of U.S. students enrolled on a study abroad (SA) program by 2020. During the 2015-16 academic year, the number of U.S. students studying abroad in an academic program increased four percent over the previous year (Institute of International Education, 2017). The emphasis on study abroad stems from institutional and national goals to better prepare students for the global economy. From a linguistic standpoint, study abroad has been shown to aid several aspects of target language (TL) development. The findings from SA research in applied linguistics demonstrate that, across languages, improvements are often seen in the areas of lexical development (cf., Fitzpatrick, 2012; Jiménez, 2010), speaking and listening abilities (cf., Cubillos, Chieffo, \& Fan, 2008; Mason, Powers, \& Donnelly, 2015), and pragmatic competence (cf., Shively, 2011).

While study abroad is considered an integral part of the U.S. higher education and language learning experience, it is surprising the low number of students of color who study abroad (Anya, 2017; Guerrero, 2006) and the fact that SA participants are still typically White, middle to upper class women (Picard, Bernardino, \& Ehigiator, 2009). Of the approximately 325,339 U.S. students who studied abroad in 2015-16, only 28.4\% were students of color (Institute of International Education, 2017). Meanwhile, according to the National Center for Education Statistics (2016), an estimated $40 \%$ of enrolled U.S. postsecondary students in fall 2014 were students of color.

This article does not intend to address why students of color do or do not study abroad. Rather, this study aims to analyze how the reactions and interpretations of students of color may 
differ from the more typical and overrepresented participant: a White female (Sweeney, 2013). More importantly, how does confronting racial and ethnic identities abroad by students of color serve as challenges or opportunities for language learning? With this information, institutions and practitioners can work towards diversifying the U.S. study abroad student population, better prepare and support students of color for their overseas programs, and create inclusive language learning curricula.

This study presents the case of two U.S. university students, Vera and Caroline (pseudonyms), in Granada and Madrid, Spain. Vera, an Iranian American, and Caroline, an African and Mexican American, are considered students of color both in the U.S. context and in Spain. By exploring the experiences of these two focal participants, this study illustrates how students of color reflect upon their racial and ethnic identities, as well as their responses to those imposed subject positionings. Lastly, this analysis demonstrates how these learners' reactions and interpretations can influence the overall quality of their language learning experiences abroad and the development of their L2 oral speaking abilities.

\section{Previous Research}

\section{Identity and Language Learning Abroad}

The shift towards the social in applied linguistics has pushed for more critical and in-depth reflections of learners' interactions and interpretations of their experiences abroad, moving beyond seeing language learners as data points to analyzing them as whole people (Coleman, 2013). An ongoing question in SA research is why students return from study abroad with varying linguistic, cultural, and personal gains (Kinginger, 2013). Why are some students more engaged in language learning than others abroad? This question is perhaps best understood in relation to identity, since how learners are positioned in language learning spaces abroad and how they interpret these actions depends on their identities (Kinginger, 2013).

Summarizing Blackledge and Pavlenko's work (2001), Block (2007) states that "identities are about negotiating new subject positions at the crossroads of past, present, and future" (p. 27). Therefore, identities are multiple, fluid, and sociohistorically shaped and constrained by ideologies (Darvin \& Norton, 2015). Given the nature of study abroad, an individual's identity may be destabilized as learners decide to negotiate, reject, or reaffirm differences between their claimed, desired, and ascribed identities. This process of identity negotiation affects one's investment, or commitment, in language learning, language use, and attitudes. As Kinginger (2013) states, "what language students learn during study abroad depends upon the kinds of access to learning opportunities that they are able to negotiate, how they evaluate the performance of identity in the contexts they frequent, and which elements of language they choose to attend to and/or incorporate into their own communicative repertoires" (p. 352). All students abroad are subject to national, foreigner, gender, age, linguistic, and/or racial and ethnic identities (Block, 2007; Kinginger 2013). The focus of this study is to examine the role of race and ethnicity in particular as they impact language learning in the SA context, given how infrequent these topics appear in the literature on study abroad.

This study defines race from a social science perspective, in which race is a social construction embedded in sociopolitical and sociohistorical contexts. Societies, cultures, and institutions have 
supported social stratification based on race and have used distinguishing physical characteristics between the 'races' (e.g., skin color, hair texture, eye shape, etc.) to make such determinations (Fish, 1995; Jones, 2003). Meanwhile, ethnicity is defined as a dynamic, multidimensional construct that refers to one's identity in terms of a subgroup who shares a common heritage within a larger context and shares similar culture, race, religion, language, history, and/or place of origin (Phinney, 1996).

\section{Students of Color Abroad}

Previous studies that focus on the role of race, ethnicity, and language learning abroad have shown mixed findings in regards to reactions from local hosts and the U.S. peers of students of color. On the one hand, Talburt and Stewart's (1999) report of Mishiela, an African American female participant in Spain, indicated that she struggled with discrimination and sexualization, which negatively impacted her cultural adjustment and willingness to engage with host country nationals. Moreover, she was the only African American student in her U.S. cohort, which further magnified her feelings of Otherness among her classmates and in Spanish society. Willis (2015) discussed similar racist and sexist aggressions towards U.S. African American female students from locals in Spain and Italy, and their American peers.

On the other hand, Anya's $(2011,2017)$ account of four African American learners of Portuguese in Salvador, Brazil, found that they experienced a greater sense of shared sociohistorical and ethno-racial identities with their host community because they were living in a context where they were part of the racial majority. As such, these learners invested heavily in learning and embodying Portuguese, particularly outside the confines of the classroom where they could exercise their full linguistic repertoire to participate and communicate. Jackson (2006) found that the experiences of students of color negotiating cultural differences in the U.S. helped them adapt to their host communities abroad. In fact, Jackson's (2006) participants stated that dealing with host country nationals was less challenging than handling their Euro-American U.S. peers' attitudes. Similarly, Davis-White Eyes' (2013) participants described their American compatriots, not their international hosts, as reproducing racist and exclusionary narratives and representations. According to Davis-White Eye (2013), the study's participants returned from their SA experience with a critical understanding of their ethno-racialized positioning in the global context and a sense of agency to enact change in the national and international conversations on difference. Likewise, Chang's (2015) U.S. Latina participants in Guatemala embraced the cultural dissonance between themselves and their Anglo-American compatriots abroad in order to reclaim a Latin American identity they believed was devalued in the U.S.

In addition, heritage language (HL) speakers_-individuals with a personal or familial connection to a language other than English in the U.S. (Beaudrie \& Fairclough, 2012)—who study in a country with familial, cultural, ethnic, or linguistic ties may encounter racial, class-based, and linguistic discrimination from host country nationals (Shively, 2016). For example, in Riegelhaupt and Carrasco's (2000) study, a Mexican-American bilingual teacher's (Lidia) Guanajuato host family criticized her for speaking a regional Spanish variety she had learned in Arizona. In Jing-Schmidt, Chen, and Zhang's study (2016), Meryl, a Chinese HL speaker, experienced racial and ethnic bias because locals treated her as "the stupid Chinese girl who can't seem to grasp anything" compared to her Euro-American peers (p.806-7). This is problematic since ethnic identity is often linked to HL 
proficiency (Mu, 2015; Sánchez, Chávez, Good, \& Wilton, 2012), even though HL speakers have varying degrees of proficiency in the HL. Nonetheless, research has also noted how HL speakers may return from SA with a renewed sense of ethno-linguistic identity, increased sociolinguistic awareness, and a reaffirmation of their HL abilities and practices (Guerrero, 2006; Quan, Pozzi, Kehoe, \& Menard-Warwick, forthcoming).

These studies illustrate that not all students of color face discrimination abroad, and in some cases, students may find the abroad climate and host community to be more welcoming than their at-home institutions or their U.S. peers. The literature suggests that the experiences of students of color are subject to both individual and contextual differences related to the SA context and, if applicable, HL proficiency. As such, there is a need to analyze the similarities and differences of how students of color of varying racial and ethnic backgrounds are positioned, and their responses to that subject positioning. With that aim, this study examines the following research questions:

1. How did these two students of color construct their identities in response to their abroad contexts in Spain?

2. What challenges and opportunities did they face abroad?

3. What impact did study abroad have on their language learning, particularly their Spanish oral proficiency?

\section{Methods and Procedures}

The two cases-Vera and Caroline-were language learners of Spanish who studied abroad between ten and sixteen weeks in Granada and Madrid, Spain, respectively, between 2014 and 2015. I recruited both participants via email through their universities' SA offices. While the initial study focused on the language outcomes of a larger group of students that included participants of different ethnicities, genders and from various SA programs, I was struck by how Vera and Caroline's cases often connected issues of race and ethnicity with feelings of incompetency and frustrations regarding their L2 Spanish learning.

This study uses a case-study approach because case studies allow researchers to explain and describe phenomena that are prone to individual differences and uncontrollable variables, such as language learning in the SA context, while highlighting themes that may be generalized to similar populations and contexts (Duff, 2012). The qualitative and quantitative data used for each case study include the following: (a) pre-departure background questionnaire, (b) pre- and post-SA Versant for Spanish oral speaking abilities test, (c) bi-weekly journals, (d) bi-weekly language contact surveys, and (e) interviews conducted the first week of, halfway through, and the last week of the program.

The Versant for Spanish oral speaking abilities test is an automatically measured and administered exam by Pearson, which tests for pronunciation, fluency, vocabulary, sentence mastery, and listening comprehension. The Versant provides an overall measurement of a participant's speaking ability in Spanish and is highly correlated with the American Council on the Teaching of Foreign Languages' (ACTFL) Oral Proficiency Interview (OPI) $(r=0.86)$ (Pearson, 2011).

The bi-weekly language contact survey asked the students to record how many hours per week they used Spanish, English or another language, with whom, where, and through which medium. 
The background questionnaire, bi-weekly language contact surveys, and interviews were conducted online and in English. The bi-weekly journal asked them to write about their language and cultural learning experiences and challenges, to reflect on their language progress and learning strategies, and to describe their interactions with the host community. The bi-weekly journals were written online and participants had the choice of writing in Spanish or English for the bi-weekly journal. See Table 1 for a summary of data collection procedures.

Table 1. Data collection procedures.

\begin{tabular}{|l|l|l|}
\hline $\begin{array}{l}\text { Pre-program } \\
\text { (during first week of program) }\end{array}$ & During the program & $\begin{array}{l}\text { Post-program } \\
\text { (during last week of program) }\end{array}$ \\
\hline $\begin{array}{l}\text { (1) Background questionnaire } \\
\text { (English) }\end{array}$ & $\begin{array}{l}\text { (1) Interview (English) } \\
\text { (2) Bi-weekly journal (Spanish or }\end{array}$ & $\begin{array}{l}\text { (1) Interview (English) } \\
\text { (2) Versant for Spanish oral speaking } \\
\text { abilities test }\end{array}$ \\
$\begin{array}{l}\text { (3) Versant for Spanish } \text { oral speaking } \\
\text { abilities test }\end{array}$ & $\begin{array}{l}\text { English) } \\
\text { (3) Bi-weekly language contact }\end{array}$ & \\
\hline
\end{tabular}

The qualitative data were coded deductively based on the research questions and analyzed for recurring themes for each participant and across the two cases (Merriam \& Tisdell, 2016). In regards to the first question about how students of color construct their identities in response to their abroad contexts, the following themes were identified: (a) rejection of racial and ethnic subject positionings that did not align with their claimed and desired identities; and (b) eventual reinterpretation of episodes for their own desired identities. In order to understand what challenges and opportunities students of color face abroad, I noted participants' interpretations of interactions and events, and the evaluative devices employed to highlight their point of view and draw attention to particular aspects of their stories (Liskin-Gasparro, 1996). I also triangulated what participants said in their journals and interviews with their bi-weekly language contact surveys. For the last question regarding how these two learners' identity construction related to their L2 learning outcomes, I compared their pre- and post-SA Versant for Spanish results.

\section{Case Studies}

The following are Vera and Caroline's case studies. Summaries of each participant's background and SA context are listed in Table 2. Interviews were recorded and transcribed verbatim by the author. All quotes are cited exactly as they were stated or written by the participants.

Table 2. Background information on case study participants

\begin{tabular}{|l|l|l|l|l|l|l|}
\hline Pseudonym & Program & Duration & Location & $\begin{array}{l}\text { Living } \\
\text { arrangement }\end{array}$ & Ethnicity & Major(s) \\
\hline Vera & $\begin{array}{l}\text { Direct enrollment at the } \\
\text { University of Granada }\end{array}$ & $\begin{array}{l}16 \text { weeks } \\
\text { (Fall 2015) }\end{array}$ & $\begin{array}{l}\text { Granada, } \\
\text { Spain } \\
\text { Ther Spanish } \\
\text { and.S. } \\
\text { roommate }\end{array}$ & $\begin{array}{l}\text { Iranian- } \\
\text { American }\end{array}$ & $\begin{array}{l}\text { Physiology \& } \\
\text { Neuroscience }\end{array}$ \\
\hline Caroline & $\begin{array}{l}\text { Literature and culture } \\
\text { program directed and } \\
\text { taught by U.S. university }\end{array}$ & $\begin{array}{l}\text { (Spring 2015) } \\
\text { (Spain }\end{array}$ & $\begin{array}{l}\text { Sost family } \\
\text { with one U.S. } \\
\text { roommate }\end{array}$ & $\begin{array}{l}\text { African- and } \\
\text { Amexican- }\end{array}$ & $\begin{array}{l}\text { Psychology \& } \\
\text { Spanish }\end{array}$ \\
\hline
\end{tabular}




\section{Vera}

Vera was a 22 year-old Iranian-American who was born in Iran but raised in Texas and Southern California. She was a neuroscience and physiology double major from a large, public university in Southern California. She studied on an SA program that allowed her to directly enroll in courses at the University of Granada and take psychology and sociology classes alongside Spanish and international students. Vera lived in an apartment with three other Spanish university students and a U.S. peer from her program. Throughout the semester, she consistently indexed herself as a committed language learner and competent student. For example, she stated in her journals and in interviews that she would try to converse with Spanish classmates, often attended her professor's office hours in Granada, and raised her hand during class lectures to participate and ask questions.

Vera's academic and housing situation in Granada, along with her self-described extroverted personality, should have provided a successful immersion experience according to previous SA research (Dewey et al., 2014). However, Vera consistently struggled to have positive relationships with local TL speakers throughout her semester and she described her efforts to engage with locals as unsuccessful. Contrary to the confident and extroverted student identity she held in the U.S., Vera consistently felt that her Spanish classmates, her roommates, and local strangers positioned her as la extranjera ('the foreigner') and the inadequate student. Vera's inability to be herself in Spanish and therefore to express her intellectual competence and extroverted personality was an ongoing struggle throughout the semester. Vera states:

I feel like a lot of the time [TL speakers] look down upon you [...] I feel stupid because of the language barrier a lot of the times. I do feel like they think I'm incompetent [...] And they try to speak English to me and I'm like no, your English is pretty broken too. I don't know, that it's kind of my own anger about it. Anyway, I do feel frustration (Mid-semester interview).

Since Vera was unable to express her knowledge in a target-like manner, her intellectual capital was devalued and prevented her from acquiring further linguistic capital since she was unable to access interactions with TL speakers. However, when the position was reversed and Vera's interlocutors attempted to speak English with her, her response was to contest how others had positioned her. By not engaging with them in English, she was also restricting their accumulation of the linguistic input that she had been denied. Just as learners are positioned by TL speakers and either denied or given access to the opportunity to speak, learners have the agency and the power to do the same. Due to Vera's negative experiences with her classmates and also her roommates, she eventually withdrew from interacting with them and spent most of her time with other international students, as indicated in her bi-weekly language surveys.

Apart from her Spanish-speaking abilities, Vera also perceived her inability to access communities of TL speakers in Spain as a product of her race and ethnicity. She believed she was positioned as an incompetent Other because of the way she looked and made the following comment: "I often get questioned a lot about what my ethnicity is, where I come from [...] I think I get a lot of stares on the street [...] a lot of the times, I do not feel accepted" (Mid-semester interview). At home in the U.S., discrimination and being the minority was not new for Vera. She had spent most of her upbringing in Texas where she was one of the only non-Anglo students at 
school. However, unlike being in the U.S., her low Spanish proficiency made it challenging to contest TL speakers' positioning of her as the inept Other in Spain. Nor was she used to how blatantly race was discussed in Spain compared to the U.S. Vera recalled the following episode in her journal that occurred on the streets of Granada.

When I was waiting for the light to change in order to cross [the street], an old Spanish man came towards me and made a gesture in front of my face and then crossed. I didn't know and I still do not know what it means. I was surprised, and I didn't know what I should do, but I was angry that a person disrespected me like that. I didn't do anything to him. Later, I saw him talking with his friend [on the street] and I said to him, 'Do you have a problem?' [in Spanish] He answered quietly with some words that I didn't understand. Honestly, I was so angry and I said to him [in Spanish] 'You're stupid' and his friend told me 'You don't understand' but the old man didn't explain what happened, so I made a gesture with my middle finger and walked away quickly. No one that I told that story to can tell me what happened with his gestures but I was surprised by the old man and his racism on the street. I realized that I am very lucky with my life. There are a lot of people that have it much worse. I am thinking about this a lot and the immigrants in a new country and the struggles (Weeks 5-6 journal entry).

Vera's attribution of this incident to racial discrimination has several interpretations. The man involved was part of the linguistic and racial majority, and therefore had the power to position her as an outsider. Moreover, according to critical race theory (CRT), the prior experiences of people of color with microaggressions and racism often lead them to "mediate life experiences and outcomes" through a racialized lens even in instances when the motivations may be ambiguous or unknown (Pérez Huber \& Solorzano, 2015, p. 301). Nevertheless, Vera decided to become an active agent in this scenario, defending herself and rejecting the racial positioning as best she could with her limited language abilities. In order to contest this discrimination and this positioning as an incompetent Other, Vera reinterprets the incident and reflects on how lucky she is, given the capital that she has compared to other immigrant groups in Spain.

In fact, there are other instances in Vera's interviews and journals where she reflects on her own sense of Otherness as an opportunity to construct an empathetic and globally-minded identity:

This whole program just makes you a more humble person because you're a person that's new to this country and people aren't accepting you and [...] when you see African people on the street begging for money. You're thinking, maybe they can't find a job because nobody wants to give them jobs. It makes you more of a global citizen (Mid-semester program interview).

Vera uses her own challenges as a student of color abroad as an opportunity to generate insight into structures of inequality and injustice in a global context.

Even though Vera gradually retracted from TL speakers, such as her Spanish classmates and housemates, she took four Spanish courses a week, approximately ten hours per week, which may explain her language improvement. Prior to her SA program, Vera had a score of 36 out of 80 on the Versant for Spanish test, and post-SA her score increased to 45 out of 80 (see Table 3). Despite 
her L2 oral gains, Vera's case illustrates how the challenges of accessing language learning spaces with TL speakers are related to identity. Vera was positioned negatively, perhaps due to the changing demographics of Spain, the increase of xenophobia towards non-White immigrants in Europe in the past two decades (United Nations, 2013) and/or the conception that linguistic ability equates to intellectual capacity. Vera was unable, despite her efforts, to have sustained and meaningful engagement with TL speakers that aligned with her claimed and desired identities, which Kinginger (2011) posits as necessary for successful language learning abroad. Unfortunately, this challenge may be a reality for students of color like Vera, who are traveling to regions where people may perceive themselves to be racially and/or ethnically homogenous, like Granada, Spain (Kleiner-Liebau, 2009).

By the end of her semester, Vera was no longer willing to interact with her Spanish roommates or classmates, and expressed periodically in her journal and interviews difficulties adjusting to Granada and Spanish culture. While she still showed linguistic improvements in her oral speaking abilities post-SA, Vera expressed a negative impression of Spanish culture and people during our final interview at the end of her program. As Sweeney (2013) warns, students of color with bad experiences abroad may hesitate to recommend their peers, which may have detrimental effects for institutions trying to promote and diversify their SA student population (p. 7).

\section{Caroline}

Caroline was a 20-year-old student who was born and raised in Southern California. She was a double major in psychology and Spanish at a large, public university in Northern California. She participated on a 10-week literature and culture program in Madrid where she took all of her courses with other U.S. students at a SA center. In Madrid, she lived with a host family and another U.S. student. Caroline identified herself on the pre-SA background questionnaire as half African and half Mexican American. Although her mother is Mexican and a native Spanish-speaker, Caroline never learned Spanish as a child, as her mother only spoke to her in English growing up.

Throughout her abroad program, Caroline desired to project the identity of a committed language learner and a competent Spanish-speaker. When she first arrived in Madrid, Caroline actively engaged with her host family and believed it would be her primary source of interaction in Spanish. Nevertheless, halfway through her program, Caroline distanced herself from her host family because she believed her host mother was positioning her as an incompetent Spanish user, creating a lot of anxiety and identity dissonance. When I asked Caroline about her host family during our mid-program interview, she provided the following description.

The family I live with is really nice but there's a lot of, I guess, cultural differences [...] I felt like my host mom was correcting me a lot [...] I guess, I'm just not used to being corrected in that way or not knowing what to do, so it was very [...] I felt just [dis]combobulated or just like, "Ugh, I don't know what to do in this situation" and it's not really comfortable (Midprogram interview).

While Caroline could have interpreted this incident and future interactions as opportunities for cultural and language learning, she chose to distance herself rather than negotiate her identity during these interactions. As a result of her host mother's criticisms, Caroline's insecurities about her Spanish language abilities, and her self-described shyness, caused her to engage in face-saving or 
passive language learning activities that did not require direct interaction with TL speakers. For example, Caroline reported in her bi-weekly language surveys spending much of her time reading because it was less stressful compared to a conversation and focused on her classes as ideal L2 learning opportunities. She admitted that she did not engage with many TL speakers during her SA program for fear of misunderstanding speakers, being misunderstood, and making mistakes.

There were so many situations where I didn't know what to say [...] I guess I focused on that more than thinking of the situations that I did understand what was going on and could respond. [...] I guess I was pessimistic in the beginning, or just very critical of myself (Postprogram interview).

As such, instead of interacting with TL speakers, she chose to spend most of her time with her American peers abroad, traveling and visiting tourist attractions. As found in previous studies, SA students who are ascribed identities that misalign with their desired identities may withdraw from the host community (e.g., Ada in Jackson, 2008), retreat towards a sense of 'national superiority' (e.g., Meryl in Jing-Schmidt et al., 2016), or choose a touristic, 'Grand Tour' approach to their SA experience (Gore, 2005).

Caroline's linguistic anxieties and her desire to present a competent Spanish-speaker identity with TL speakers is also related to her Mexican heritage. During our post-SA interview, I asked her if she would continue learning Spanish and she stated the following.

When I think of Spanish, I think of it as being an integral part of my ancestry and just like Latin people as a whole. So to not be able to speak Spanish like I would like to is, like thinking that other people wouldn't consider me as Mexican as I would like. I think that was also something that I had to realize. Me embracing that culture, embracing both cultures, it's a journey too and not something that other people can dictate (Post-program interview).

Caroline's criticalness towards her own language development stems from the belief that speaking Spanish well is a requirement for claiming a Mexican ethnic identity. This link between ethnic identity and HL proficiency $(\mathrm{Mu}, 2015)$ is an ideology that many Spanish heritage speakers internalize as a result of Spanish native speakers expecting them to have monolingual cultural and linguistic norms (Leeman, 2015). According to Sánchez et al. (2012), Latino/as who perceive themselves to have limited Spanish proficiency often feel greater intragroup rejection, lower collective self-esteem, and are less likely to self-identify as Latino/a. However, as her SA program ended, Caroline eventually realizes that she has the agency, not other people, to dictate how to enact and claim her identities as a Spanish-speaker/learner, and as Mexican American.

As the SA program progressed, Caroline withdrew from TL speakers, spending most of her time abroad reading and listening to Spanish, and interacting with other L2 Spanish learners, like her U.S. classmates. Still, she remained committed to learning Spanish, which may explain her improvement. She continued to write her journal in Spanish throughout the semester and was dedicated to performing well in her SA classes. Prior to her SA program, Caroline had a score of 41 out of 80 on the Versant for Spanish test, and post-SA, her score improved to 50 out of 80 (see Table 3). 
Unfortunately, for Caroline, the short time frame of her program — ten weeks — gave her little time to overcome emotional and social obstacles. Caroline's case, like that of Vera's, suggests a greater need for SA programs to provide emotional and mental support and guidance in how to interpret episodes that may cause identity dissonance and missed language learning opportunities. For Caroline, her ethnic identity influenced her views on Spanish language learning and use, and her subsequent reactions to TL speakers. If the aim is to diversify the student population abroad, SA programs may wish to reevaluate their curriculum since it is traditionally designed for L2 learners with no ancestral or familial ties to the language (Kinginger, 2013). Furthermore, accessing occasions to interact in the TL is difficult for all students, but especially for self-critical, anxious and/or timid ones (Knight \& Schmidt-Rinehart, 2010). As such, SA programs may want to make students explicitly aware of the added challenge of overcoming shyness abroad ahead of time, or create more opportunities to bridge participants with TL speakers through organized intercambios ('language partners'), structured host family events, or volunteer and internship opportunities.

\section{Discussion}

Vera and Caroline's cases illustrate how students of color might reject subject positionings that challenge their claimed identities. Instead, they may choose to reinterpret episodes for their own desired identities, which can have both positive and negative outcomes. On the one hand, it leads to missed language learning opportunities, while on the other, it can encourage self-awareness and selfreflection. According to my first research question regarding how these two participants constructed their identities in response to their contexts in Spain, Vera and Caroline both contested their ascribed identities as incompetent users or speakers of Spanish throughout their time abroad. They both eventually recognized their agency to re-align themselves according to their desired identities: Vera as an empathetic and globally minded individual and Caroline as a legitimate Mexican American Spanish speaker and learner. However, this negotiation occurred in their journals and interviews with me.

Vera and Caroline did not apply their reflections and negotiated identities to their relationships and lives while they were in Spain. According to other researchers, SA students may benefit from intervention during their SA programs. Lee (2011) found that U.S. students who engaged in critical reflection on cross cultural issues through blogging and ethnographic interviews with TL speakers during their semester abroad developed their intercultural competence. Additionally, intercultural mentors on site who will encourage SA learners to "reflect on what and how they are learning, to become culturally self-aware, to suspend hasty (and frequently negative) judgments in responding to people and events, to learn to communicate flexibly" (p. 30) can lead to greater intercultural learning post-SA (Vande Berg, Connor-Linton \& Paige, 2009). Perhaps if Vera and Caroline were guided through further reflection and how to apply these insights, Vera might have pursued different relationships, and Caroline might have taken advantage of the language learning opportunities available to her. As Sol (2017) suggests, guided intervention, such as experiential learning and reflective journaling, can facilitate understanding of one's own identity, which is key to understanding another's culture.

For the second question regarding the challenges and opportunities both participants faced abroad, Caroline retracted from interactions with TL speakers because it made her feel anxious and an inadequate Spanish-speaker and illegitimate Mexican American. Unlike previous studies that have 
found racism and sexism to permeate African American female experiences in Spain (e.g., Talburt \& Stewart, 1999; Willis, 2015), Caroline never attributed her negative experiences and feelings to explicit racial or ethnic discrimination. Nonetheless, Caroline's narratives reflect ideologies on how she should speak Spanish given her heritage background. This aligns with previous researchers $(\mathrm{Mu}$, 2015; Sánchez et al., 2012; Yu, 2013) who have shown how ethnic identity, self-esteem, and HL proficiency influences one another. Yet the question of why Caroline's African American background did not play into her experiences in Spain remains an open question. Since the original aim of this study did not focus on race nor ethnicity, I did not explicitly ask Caroline about her experiences as a biracial or Black woman in Spain. Perhaps Caroline's focus on her Spanish proficiency shifted her interpretations of her SA experience to center on her Mexican American identity, rather than that of her African American identity.

In contrast, Vera believed she was repeatedly positioned by classmates and roommates as the foreign Other on account of her race, ethnicity, and L2 Spanish abilities. Subsequently, Vera became less invested in engaging with TL speakers. However, unlike Caroline, Vera used these challenges as an opportunity to reflect critically on her own sense of Otherness, to recognize relations of power, and to realize her privileges compared to other minorities and immigrants in Spain. Vera's selfreflection and criticality are empowering post-SA outcomes that seem to emerge for some students of color abroad (e.g., Anya, 2017; Davis-White Eyes, 2013), warranting further research into how the SA experience can transform and benefit students beyond language learning. Moreover, it is important to recognize that the challenges faced by students of color may include obstacles both external (discrimination, prejudice, and ideologies) and internal (psychological or emotional).

In regards to the last research question on the impact study abroad had on their L2 Spanish oral proficiency, both cases showed language gains post-SA, as demonstrated by their improvements on the Versant for Spanish test. However, they both improved by nine points (see Table 3) despite Vera being on a 16-week program versus Caroline's 10-week program. Vera's case questions whether she could have improved more if she had received more program support or had accessed more diverse language learning opportunities that aligned with her desired empathetic and globally-conscious identity. Furthermore, despite measured gains on their oral speaking abilities, Vera and Caroline did not express feeling like more confident Spanish-speakers, which some researchers (e.g., Surtees, 2016) would argue should be a desired outcome of study abroad as well.

Table 3. Versant for Spanish oral speaking abilities test results (max score of 80)

\begin{tabular}{|l|l|l|l|l|}
\hline Participant & $\begin{array}{l}\text { Pre-SA } \\
\text { Versant }\end{array}$ & Corresponding ACTFL-OPI level & $\begin{array}{l}\text { Post-SA } \\
\text { Versant }\end{array}$ & Corresponding ACTFL-OPI level \\
\hline Vera & 36 & Intermediate low & 45 & Intermediate mid \\
\hline Caroline & 41 & Intermediate low & 50 & Intermediate mid \\
\hline
\end{tabular}




\section{Conclusion and Implications}

In sum, Vera and Caroline's cases demonstrate both positive and negative possibilities for students of color studying abroad. There are several implications that their experiences may have on the design and implementation of SA programs that are inclusive of and transformative for underrepresented students. First, these two cases demonstrate that students interpret, attribute, and respond to the abroad experience for their own desired identities. As such, educators and administrators can advise and prepare future students for how they may be positioned when they are abroad, especially for students whose identities may be questioned and/or delegitimized. Predeparture orientations and resources should highlight how students may possibly experience discrimination that differs from their at-home experiences, or that interactions may be interpreted as racially or ethnically-charged depending on students' prior experiences. Faculty and staff at-home and abroad could identify challenges other students of color have encountered on similar programs and provide on-site support for them. This may come in the form of culture classes where learner experiences are reflected upon and contextualized (cf., Talburt \& Stewart, 1999), or with trained counselors/mentors that may act as allies when students encounter challenges abroad.

Second, tracking SA students' language progress may combat feelings of linguistic insecurity and self-doubt, which Caroline felt repeatedly. Both Vera and Caroline reported that the pre- and post-SA Versant test results showed them concrete evidence that they had improved, which they had doubted prior to those results. Third, how host-country nationals position students of color is contextual. Vera and Caroline's experiences may have been different in another country, Spanishspeaking or otherwise, because their racial, ethnic, national, and gender identities would have differing implications. For instance, the overall positive outcomes from Anya $(2011,2017)$ and Chang (2015) were different from this study's findings due to the combination of host country and student backgrounds. As such, when advising students about which country to study abroad, it is important to keep context in mind. More SA research, like this one, examining different ethno-racial identities across national contexts is needed.

Fourth, the SA context served as a site of identity reflection and negotiation for both participants. With this in mind, SA programs should encourage opportunities for such reflection to occur through journals, interviews, and/or blogs, similar to the tools used in this study and those suggested by other researchers (Kinginger, 2011; Vande Berg, Paige, \& Lou, 2012). Students would benefit from having teachers and program directors abroad who are aware of these negotiations of identity, who will provide insight, and who will encourage students to apply these understandings to their lives abroad. Opportunities for reflection are extremely important not only during the abroad program, but also afterwards, since how SA will affect learners in the long-term is also an important consideration.

Lastly, if the intention is to diversify and be inclusive of all students in the abroad experience, then researchers, educators, and administrators should listen to the experiences of students of color and other underrepresented students (e.g., students with disabilities, LGBTQ students) abroad across a range of national contexts. Moreover, echoing Anya's observations (2017) and Pennycook's assertions (2001), instructors and SA directors should be cognizant of what is left out or what is left unsaid in language classrooms and SA programs. If we wish to promote inclusivity, then we must recognize how materials, topics, programming and curricula may reproduce racist, elitist, sexist, and 
homophobic discourses that marginalize certain students. We want a greater diversity of students to study abroad, but we also want them to be successful and have positive abroad experiences. In order to achieve this goal, SA research should continue to broaden their participant pool to include atypical SA learners who have distinct perspectives and experience different outcomes in the abroad context.

\section{References}

Anya, U. (2011). Investments in communities of learners and speakers: How African American students of Portuguese negotiate ethno-racialized, gendered, and social-classed identities in second language learning (Unpublished doctoral dissertation). University of California, Los Angeles, California.

Anya, U. (2017). Racialized identities in second language learning. New York, NY: Routledge.

Beaudrie, S. \& Fairclough, M. (Eds.). (2012). Spanish as a heritage language in the United States: The state of the field. Washington D.C.: Georgetown University Press.

Blackledge, A., \& Pavlenko, A. (2001). Negotiation of identities in multilingual contexts. The International Journal of Bilingualism Introduction, 5(3), 243-257.

Block, D. (2007). Second language identities. London: Continuum.

Chang, A. (2015). "Call me a little critical if you will": Counterstories of Latinas studying abroad in Guatemala. Journal of Hispanic Higher Education, DOI: 10.1177/1538192715614900

Coleman, J. A. (2013). Researching whole people and whole lives. In C. Kinginger (Ed.), Social and cultural aspects of language learning in study abroad (pp. 17-44). Amsterdam: John Benjamins.

Cubillos, J. H., Chieffo, L., \& Fan, C. (2008). The Impact of short-term study abroad programs on L2 listening comprehension skills. Foreign Language Annals, 41(1), 157-186.

Darvin, R., \& Norton, B. (2015). Identity and a model of investment in applied linguistics. Annual Review of Applied Linguistics, 35, 36-56.

Davis-White Eyes, A. (2013). (re)Presenting in a global village: Students of color and the study abroad international experience (Unpublished doctoral dissertation). Oregon State University, Corvallis, Oregon.

Dewey, D. P., Bown, J., Baker, W., Martinsen, R. A., Gold, C., \& Eggett, D. (2014). Language use in six study abroad programs: An exploratory analysis of possible predictors. Language Learning, 64(1), $36-71$.

Duff, P. A. (2012). How to Carry Out Case Study Research. In A. Mackey \& S. M. Gass (Eds.), Research methods in second language acquisition: A Practical Guide (pp. 95-116). Malden, MA: WileyBlackwell.

Fish, J. M. (1995). Why psychologists should learn some anthropology. American Psychologist, 50(1), 44-45.

Fitzpatrick, T. (2012). Tracking the changes: Vocabulary acquisition in the study abroad context. Language Learning Journal, 40(1), 37-41.

Gore, J. E. (2005). Dominant beliefs and alternative voices: Discourse, belief, and gender in American study abroad. New York: Routledge.

Guerrero, E. (2006). The road less traveled: Latino students and the impact of studying abroad (Unpublished doctoral dissertation). University of California, Los Angeles, California.

Institute of International Education. (2017). Open Doors Report on International Educational Exchange. Retrieved from https://www.iie.org/en/Research-and-Insights/Open-Doors

Jackson, J. (2008). Language, identity and study abroad: Sociocultural perspectives. London: Equinox Publishing Ltd.

Jackson, M. J. (2006). Traveling shoes: Study abroad experiences of African American students participating in California State University international programs (Unpublished doctoral dissertation). University of San Francisco, San Francisco, California.

Jiménez, A. (2010). A comparative study on second language vocabulary development: Study abroad vs classroom settings. Frontiers: The Interdisciplinary Journal of Study Abroad, 19, 105-124. 
Jing-Schmidt, Z., Chen, J. Y., \& Zhang, Z. (2016). Identity development in the ancestral homeland: A Chinese heritage perspective. Modern Language Journal, 100(4), 797-812.

Jones, J. M. (2003). Constructing race and deconstructing racism: A cultural psychology approach. In G. Bernal, J. E. Trimble, A. K. Burlew, \& F. T. L. Leong (Eds.), Handbook of racial \& ethnic minority psychology (pp. 276-290). Thousand Oaks, CA: Sage.

Kinginger, C. (2011). Enhancing language learning in study abroad. Annual Review of Applied Linguistics, 31, 58-73.

Kinginger, C. (2013). Identity and language learning in study abroad. Foreign Language Annals, 46(3), 339-358.

Kleiner-Liebau, D. (2009). Migration and the construction of national identity in Spain. Madrid, Spain: Iberoamericana.

Knight, S. M., \& Schmidt-Rinehart, B. C. (2010). Exploring conditions to enhance student/host family interaction abroad. Foreign Language Annals, 43(1), 64-71.

Lee, L. (2011). Blogging: Promoting learner autonomy and intercultural competence through study abroad. Language Learning \& Technology, 15(3), 87-109.

Leeman, J. (2015). Heritage language education and identity in the United States. Annual Review of Applied Linguistics, 35, 100-119.

Liskin-Gasparro, J. E. (1996). Narrative strategies: A case study of developing storytelling skills by a learner of Spanish. Modern Language Journal, 80(3), 271-286.

Mason, L., Powers, C., \& Donnelly, S. (2015). The Boren awards: A report of oral language proficiency gains during academic study abroad. Institute of International Education, 1-25. Retrieved from https://www.iie.org/Research-and-Insights/Publications/The-Boren-Awards-A-Report-of-OralLanguage-Proficiency-Gains

Merriam, S., \& Tisdell, E. (2016). Qualitative research: A guide to design and implementation (4th ed.). San Francisco, CA: Jossey-Bass.

$\mathrm{Mu}, \mathrm{G}$. M. (2015). A meta-analysis of the correlation between heritage language and ethnic identity. Journal of Multilingual and Multicultural Development, 36(3), 239-254.

National Center for Education Statistics. (2016). Total fall enrollment in degree-granting institutions, by level of student, sex, attendance status, and race/ethnicity: Selected years, 1976 through 2014. Retrieved from http://nces.ed.gov

Pearson. (2011). Versant Spanish test: Test description and validation summary. Retrieved from http://www.versanttest.com/technology/VersantSpanishTestValidation.pdf

Pennycook, A. (2001). Critical applied linguistics: A critical introduction. Mahwah, NJ: Lawrence Erlbaum Associates.

Pérez Huber, L., \& Solorzano, D. G. (2015). Racial microaggressions as a tool for critical race research. Race Ethnicity and Education, 18(3), 297-320.

Phinney, J. S. (1996). When we talk about American ethnic groups, what do we mean? American Psychologist, 51(9), 918.

Picard, E., Bernardino, F., \& Ehigiator, K. (2009). Global citizenship for all: Low minority participation in study abroad seeking strategies for success. In R. Lewis (Ed.), The Handbook of practice and research in study abroad: Higher education and the quest for global citizenship (pp. 321-345). New York, NY: Routledge.

Quan, T., Pozzi, R., Kehoe, S. \& Menard-Warwick, J. (forthcoming). Spanish Heritage Language Learners in Study Abroad Across Three National Contexts. In Sanz, C. \& Morales Front, A. (Eds.), Routledge Handbook of Study Abroad. New York, NY: Routledge.

Riegelhaupt, F., \& Carrasco, R. (2000). Mexico host family reactions to a bilingual Chicana teacher in Mexico: A case study of language and culture clash. Bilingual Research Journal, 24(4), 405-421.

Sánchez, D. T., Chávez, G., Good, J. J., \& Wilton, L. S. (2012). The language of acceptance. Journal of Cross-Cultural Psychology, 43(6), 1019-1033.

Shively, R. (2011). L2 pragmatic development in study abroad: A longitudinal study of Spanish service encounters. Journal of Pragmatics, 43, 1818-1835. 
Shively, R. L. (2016). Motivations, identity work, and language development. In D. Pascual y Cabo (Ed.), Advances in Spanish as a Heritage Language (pp. 259-280). Philadelphia: John Benjamins Publishing Company.

Sol, N. (2017). Fostering intercultural identity during study abroad to strengthen intercultural competence. In L. Leavitt, S. Wisdom, \& K. Leavitt (Eds.), Cultural awareness and competency development in higher education (pp. 325-345). Hershey, PA: IGI Global.

Surtees, V. (2016). Beliefs about language learning in study abroad: Advocating for a language ideology approach. Frontiers: The Interdisciplinary Journal of Study Abroad, 27, 85-103.

Sweeney, K. (2013). Inclusive excellence and underrepresentation of students of color in study abroad. Frontiers: The Interdisciplinary Journal of Study Abroad, 23, 1-21.

Talburt, S., \& Stewart, M. A. (1999). What's the subject of study abroad?: Race, gender, and "living culture." Modern Language Journal, 83(2), 163-175.

United Nations. (2013). Spain must make fighting racism and xenophobia a priority. United Nations News Centre. Retrieved from http://www.un.org/apps/news/story.asp?NewsID=44013\#.WdqLmhSw2w

Vande Berg, M., Connor-Linton, J., \& Paige, R. M. (2009). The Georgetown consortium project: Interventions for student learning abroad. Frontiers: The Interdisciplinary Journal of Study Abroad, $18,1-75$.

Vande Berg, Paige, R.M., \& Lou, K.H. (Eds.). (2012). Student learning abroad: What our students are learning, what they're not, and what we can do about it. Sterling, VA: Stylus.

Willis, T. Y. (2015). "And still we rise...:" Microaggressions and intersectionality in the study abroad experiences of black women. Frontiers: The Interdisciplinary Journal of Study Abroad, 26, 209-230.

Yu, S. (2013). The relationships among heritage language proficiency, ethnic identity, and self-esteem (Unpublished doctoral dissertation). DePaul University, Chicago, Illinois. 